\title{
Research on Wuhan Sponge City Construction and Water Resumption System
}

\author{
Hongmin $\mathrm{Li}^{1, *}$, and $L u \mathrm{Yan}^{2}$ \\ ${ }^{1}$ School of Civil Engineering and Architecture, Wuhan Polytechnic University, Wuhan, China \\ ${ }^{2}$ Hubei Audit Office, Wuhan, China
}

\begin{abstract}
Pocket parks are small public spaces between building entities which are available to the public. It can be located in a city, suburb, or country. It has a small area and is relatively flexible. According to the characteristics of China's cities, this article puts forward methods and measures for the landscape reconstruction design of existing urban communities in China. The thesis takes a Residential area of a certain district in Wuhan as a design case. It discusses how to combine the landscape design of the existing community with the rainwater problem, the goals, principles and measures of the landscape reconstruction design of the existing community based on the sponge city concept are proposed. Using rainwater as a resource to collect, purify, store, and recycle, alleviate water shortages and urban flood disasters, and it summarizes the methods and strategies for landscape reconstruction design of existing communities. Finally, according to the problems in the residential area and the actual needs of residents, combined with the current conditions of the site, following the design principles of people-oriented and local conditions, the use of sponge city technology measures on the green landscape, roads and parking lots, rooftop landscape of underground garages, plants Matching and other specific reconstruction designs provide theoretical and design references for the application of the "sponge city" concept in the design of urban residential quarters.
\end{abstract}

\section{Introduction}

The Ministry of Housing and Urban-Rural Development issued the "Sponge City Construction Technology Guide", so the definition of the concept of "sponge city" is very clearly. That is, the city which is like sponges, it has good "elasticity" in adapting to environmental changes and responding to natural disasters. It absorbs, stores, seeps, and purifies water when it rains, and "releases" and uses the stored water when needed. The six-character policy of sponge city design is "seepage, stagnation, storage, cleanliness, usage, drainage". In the landscape design of the existing community, it can replace the traditional gray foundation measures, using green roofs, ecological grass trenches, and water permeability. Pavement, rain garden, wetland and others are measures are to promote rainwater infiltration ability, while purifying and storing rainwater. It is beneficial to alleviate the flood disaster, water shortage and water pollution in the existing community, and can help restore the balance of the urban ecosystem.

In the three years from 2012 to 2015 , more than 360 cities in China suffered from flooding. In order to improve the urban ecological environment, eliminate the hidden dangers of urban waterlogging, our government proposes to build sponge cities with natural accumulation, natural penetration, and natural purification, it has been mentioned at the national strategic level. In October 2014, the Ministry of Housing and Urban-Rural Development issued The "Technical Guide for Sponge City Construction-Low Impact Development Rainwater System Construction (Trial)" was launched. In January 2015, the sponge cities were started to construct in 16 pilot cities including Zhenjiang, Jiaxing, Xiamen, Jinan, and Wuhan.

In foreign countries such as the United States, Japan, Australia, and some European countries, the practices of urban water resources management started earlier. They proposed "BMPs Best Management Practices", "LID low-impact development technology", and "WSUD water-sensitive urban design." The concepts have been well applied in urban planning and design, and can provide good references for our country.

\section{Design principles of residential quarters based on the concept of sponge city pocket park}

\subsection{Pocket park concept}

The pocket park is a small public space between the building entities for public use. It can be located in a city, suburb, or country. It has a small area and is relatively flexible. In foreign countries it is usually built on vacant plots of land or buildings, or it can be created as part of the public space requirements of large construction projects. There are different definitions of pocket parks

\footnotetext{
$\bar{*}$ Corresponding author: $313833354 @$ qq.com
} 
in China. Some scholars believe that pocket parks are small public open spaces located in outdoor environments, with small areas and pleasant scales. As a part of urban green space and public space, pocket parks provide good ecosystem services for the city and promote the development of residents' mental health and physical activity.

At present, research and construction of pocket parks at home and abroad are increasing. Due to the diversity of pocket park types, urban pocket parks can be divided into different types according to different classification standards. It can be divided into six categories according to the types of urban land served by pocket parks: parktype pocket parks, residential pocket parks, office pocket parks, Public service pocket parks, business pocket parks and road pocket parks.

The predecessors carried out a lot of research on the design principles of pocket parks, which can be summarized as: safety principles, humanization principles, high-efficiency principles, openness principles, and sustainability principles. In combination with actual cases, this article introduces the principles of residential landscape design and the selection of related features and facilities.

\subsection{Principle and benefits of pocket park}

\subsubsection{Low Impact Development Principle}

The concept of low-impact development means that the hydrological characteristics of the site remain the same before and after development, also known as low-impact design (Low Impact Design, LID).

The city's traditional development model is largescale and high-intensity, which destroys the natural ecology extremely severely, and the site's hydrological characteristics show significant damage before and after development. Low-impact development emphasizes that in the process of urban development, the degree of impact on the surrounding aquatic environment is minimized to achieve coordinated development of the city and natural resources. Low-impact development is a comprehensive management of rainwater peak flow control and delay of flood peaks, mainly through various technical measures such as infiltration, filtration, storage, purification, evaporation, and dispersed runoff. From the perspective of the hydrological cycle, in order to maintain the total site runoff, different technical measures must be adopted for the initial, middle and later rainwater and a decentralized source control mechanism. In the early stage of rainwater, the source of rainwater is reduced to realize part of the rainwater seepage and filtration. In the medium term, the rainwater runoff is quickly diverted to flow into different rainwater storage facilities to infiltrate, detain, and filter. Purification, storage, and storage and storage of rainwater at the same time, the whole process achieves the purpose of low-impact development and control of urban rainwater storage and storage. The construction of urban pocket parks should include low-impact development content in planning, design, implementation and other links, and coordinate the construction of urban roads, large urban parks, and urban buildings to jointly achieve the low-impact development control goals. In the process of urban development in China, problems such as urban waterlogging, rainwater pollution, and water shortages should occur. During the development and construction of its site, technical routes such as rainwater source depletion control, mid-term rainwater flow, and terminal comprehensive purification watershed runoff should be used. This provides constructive help to rainwater management for pocket parks.

\subsubsection{Rainwater recycling, enhancing ecological benefits}

Community parks or green spaces not only provide open green space for urban residents, but also play an important role in urban construction and development. While satisfying people's basic leisure and entertainment purposes, they should have certain flood prevention and flood discharge capabilities. As a part of the rainwater management facilities in sponge cities, community parks or green spaces have the functions of restoring natural water circulation, infiltration, evaporation, and biological utilization, and alleviating urban flooding. Therefore, they have high urban "water benefits". Especially in areas where water resources are scarce and groundwater levels are falling, the ecological benefits brought by pocket parks are even more significant.

In addition to its ability to fix carbon and release oxygen, plants also have the ability to filter and purify the surrounding particulates.

Natural landscape and suitable climatic conditions can provide a good habitat for animals and microorganisms.

\subsection{Related facilities}

\subsubsection{Water storage facility}

Rainwater storage is an integral part of integrated water resources management, which can reduce the pressure of interregional water transfer. The commonly used methods include underground detention systems, rainwater culverts, and sunken greenbelt. Underground Detention Systems (UDS) are temporary rainwater retention and slow infiltration rainwater storage devices. Depends on the underlying soil with good permeability, and slowly releases stored rainwater to the sponge city facility network. Rainwater collection pool (RCP) is a permanent underground structure used to store rainwater. The goal is to slow down stormwater runoff, quickly remove rainwater, and remove more sediment. Such as underground cisterns. Sunken Greenbelt (SG) is one of the most common low-cost, low-impact rainwater treatment facilities in urban sponges. By lowering its own elevation and using its storage volume to collect rainwater in the site, it has the effect of stagnating rainwater, intercepting rainwater in heavy rains, and alleviating the pressure of municipal drainage network 
drainage facilities. The characteristics of each collection and storage facilities are shown in Table 1.

Table 1. Characteristic table set, water storage facilities

\begin{tabular}{|c|c|c|c|}
\hline facilities & UDS & RCP & SG \\
\hline $\begin{array}{c}\text { Service } \\
\text { level }\end{array}$ & $\begin{array}{c}\text { Stranded/penetra } \\
\text { tion }\end{array}$ & storage & $\begin{array}{c}\text { Stranded/pe } \\
\text { netration }\end{array}$ \\
\hline $\begin{array}{c}\text { in the lower part } \\
\text { of the filtration } \\
\text { system to } \\
\text { prevent } \\
\text { excessive } \\
\text { sediment from } \\
\text { affecting the } \\
\text { water storage }\end{array}$ & $\begin{array}{c}\text { upstream of } \\
\text { purification } \\
\text { treatment } \\
\text { facility, } \\
\text { downstream of } \\
\text { filtration facility }\end{array}$ & $\begin{array}{c}\text { Located } \\
\text { above the } \\
\text { water } \\
\text { storage } \\
\text { system }\end{array}$ \\
$\begin{array}{c}\text { Applicabl } \\
\text { e scale }\end{array}$ & $\begin{array}{c}\text { Catchment area } \\
\text { up to 1 ha }\end{array}$ & $\begin{array}{c}\text { Dolermine its } \\
\text { the runoff area } \\
\text { of the catchment } \\
\text { area }\end{array}$ & $\begin{array}{c}\text { Determined } \\
\text { according to } \\
\text { rainwater } \\
\text { runoff } \\
\text { coefficient } \\
\text { and site area }\end{array}$ \\
\hline $\begin{array}{c}\text { Manage } \\
\text { ment } \\
\text { measures }\end{array}$ & $\begin{array}{c}\text { Check and } \\
\text { eliminate } \\
\text { sediment to } \\
\text { prevent clogging }\end{array}$ & $\begin{array}{c}\text { Special } \\
\text { equipment is } \\
\text { nemoded to } \\
\text { and sediment at } \\
\text { the bottom of the } \\
\text { pool }\end{array}$ & $\begin{array}{c}\text { Plant } \\
\text { conservation } \\
\text { to avoid } \\
\text { pesticides, } \\
\text { etc., to } \\
\text { remove } \\
\text { garbage }\end{array}$ \\
\hline
\end{tabular}

\subsubsection{Water purification facilities}

In addition to water collection and storage, rainwater management measures also include rainwater infiltration and purification measures. Infiltration methods are used to reduce urban drainage pressure and supplement urban groundwater. The facilities in the pocket park for sponge and rainwater infiltration include underground sand beds, plant filter belts, permeable paving, infiltration trenches, and ecological tree ponds. Underground Sand Niter (USN) is an underground physical filtration system that provides filtering and temporary storage of rainwater from the road surface. To a certain extent, it has made up for the space limitation of insufficient permeable drainage area in high-density urban core areas. Pervious Pavings (PP) is to provide a channel for rainwater to penetrate into the underground natural soil, and to filter the sediment and other pollutants in the rainwater, and to reduce rainwater runoff and flow rate, which can achieve preliminary water purification effect. Permeable paving on the market mainly includes permeable concrete, permeable asphalt, grass bricks, and so on. Grassed Swales (GS) is a shallow surface ditch for planting vegetation. It has a landscape drainage system and can be called a biological ditch. It mainly slows down the speed of rainwater runoff and the preliminary purification treatment of rainwater, which can largely maintain the water surface for a long time, creates a suitable environment for microbial survival, increases biodiversity, and brings people a specific landscape visual experience. Rain infiltration filter facilities are shown in table 2.
Table 2. Rain infiltration filter facilities characteristic table

\begin{tabular}{|c|c|c|c|}
\hline $\begin{array}{c}\text { facilitie } \\
\text { s }\end{array}$ & USN & PP & GS \\
\hline $\begin{array}{c}\text { Service } \\
\text { level }\end{array}$ & Stranded/filter & $\begin{array}{c}\text { filter/penetrati } \\
\text { on/treatment }\end{array}$ & $\begin{array}{c}\text { filter/Purificati } \\
\text { on }\end{array}$ \\
\hline $\begin{array}{c}\text { Locatio } \\
\text { n in } \\
\text { Pocket } \\
\text { Park }\end{array}$ & $\begin{array}{c}\text { Located on the } \\
\text { parking lots, } \\
\text { sidewalks, } \\
\text { Pocket Park, } \\
\text { filtering the first } \\
\text { wave of rain } \\
\text { upstream of } \\
\text { other } \\
\text { rainwater } \\
\text { treatment } \\
\text { facilities }\end{array}$ & $\begin{array}{c}\text { fownstream of } \\
\text { filtration } \\
\text { facility, } \\
\text { upstream of the } \\
\text { main } \\
\text { purification } \\
\text { treatment } \\
\text { facility }\end{array}$ \\
\hline $\begin{array}{c}\text { Applica } \\
\text { ble } \\
\text { scale }\end{array}$ & $\begin{array}{c}\text { Small water } \\
\text { accumulation } \\
\text { with runoff area } \\
\text { of 0.5-4hm }\end{array}$ & $\begin{array}{c}\text { Small venue, } \\
\text { parking lot }\end{array}$ & $\begin{array}{c}\text { At least } 0.5 \mathrm{~m}^{2} \\
\text { parking }\end{array}$ \\
\hline $\begin{array}{c}\text { Manage } \\
\text { ment } \\
\text { measure } \\
\text { s }\end{array}$ & $\begin{array}{c}\text { Regular cleaning } \\
\text { and replacement } \\
\text { of sand }\end{array}$ & $\begin{array}{c}\text { road needs to } \\
\text { clean, grass } \\
\text { planting needs } \\
\text { maintenance }\end{array}$ & $\begin{array}{c}\text { Regular } \\
\text { cleaning of } \\
\text { trash and plant } \\
\text { pruning }\end{array}$ \\
\hline
\end{tabular}

The pocket park sponges' measures for rainwater purification mainly include biological retention facilities. Filter Trip (FT) is mainly used to filter large particles of sediment in rainwater runoff, and by planting plants to slow down the flow rate, the suspended sediment and debris are separated from the runoff.

Table 3. The characteristic table of water cleaning facility

\begin{tabular}{|c|c|c|c|}
\hline & FT & $\mathrm{RG}$ & ETP \\
\hline $\begin{array}{c}\text { Service } \\
\text { level }\end{array}$ & filter & $\begin{array}{c}\text { filter/penetratio } \\
\text { n/treatment }\end{array}$ & $\begin{array}{c}\text { filter/penetratio } \\
n\end{array}$ \\
\hline $\begin{array}{c}\text { Locatio } \\
\mathrm{n} \text { in } \\
\text { Pocket } \\
\text { Park }\end{array}$ & $\begin{array}{l}\text { Located } \\
\text { upstream of the } \\
\text { rainwater } \\
\text { treatment } \\
\text { system, the } \\
\text { preliminary } \\
\text { treatment of } \\
\text { rainwater } \\
\text { collection }\end{array}$ & $\begin{array}{l}\text { Located } \\
\text { downstream of } \\
\text { the filtration } \\
\text { equipment and } \\
\text { upstream of the } \\
\text { purification } \\
\text { treatment } \\
\text { facility }\end{array}$ & $\begin{array}{l}\text { The first step to } \\
\text { purify } \\
\text { rainwater, } \\
\text { replacing } \\
\text { traditional tree } \\
\text { and flower } \\
\text { ponds in pocket } \\
\text { parks }\end{array}$ \\
\hline $\begin{array}{l}\text { Applica } \\
\text { ble scale }\end{array}$ & $\begin{array}{l}\text { Linearly } \\
\text { arranged along } \\
\text { a street or tree- } \\
\text { lined road }\end{array}$ & $50 \mathrm{~m}^{2}$ & $\begin{array}{c}\text { From a single } \\
\text { tree pool to a } \\
\text { continuous } \\
\text { green belt } \\
\text { network } \\
\end{array}$ \\
\hline$\left|\begin{array}{c}\text { Manage } \\
\text { ment } \\
\text { measure } \\
\mathrm{s}\end{array}\right|$ & $\begin{array}{l}\text { Maintain plant } \\
\text { growth, remove } \\
\text { trash and } \\
\text { sediment }\end{array}$ & $\begin{array}{l}\text { Waste removal, } \\
\text { plant trimming, } \\
\text { etc. }\end{array}$ & $\begin{array}{l}\text { Waste removal, } \\
\text { keeping the } \\
\text { cover intact and } \\
\text { good } \\
\text { permeability }\end{array}$ \\
\hline
\end{tabular}

Rain Garden (RG) is a sustainable rainwater flood control and rainwater utilization facility, which mainly regulates the storage, infiltration and purification of rainwater through the combined effects of plants, soil and microbial systems. It mainly absorbs rainwater from streets and buildings, with a small scale, but has a rich variety of plants. The Ecological Tree Pool (ETP) is a planting container composed of a cover layer, a filter medium, a planting soil layer and a porous drainage pipe. 
The filter media and plant roots in the tree pond can absorb and decompose rainwater pollutants, and the planting soil in the tree pond can play a natural water storage function. The characteristics of its water purification facilities are shown in Table 3.

\section{Reconstruction design method of a residential quarter in Wuhan}

\subsection{Landscape design}

The rainwater is purified by the adsorption function of the plants. The rainwater is recycled after treatment or discharged into the municipal rainwater pipe network, which can avoid water pollution and protect the environment. The rain garden also brought vitality to the entire community. Through the contrast of space and rhythm, and greenery, the site was more attractive, allowing people to stay and rest and play, creating a comfortable landscape space for residents. The beneficial role of water resources can not only meet the visual needs of people, but also regulate the microclimate and maintain the balance of the ecosystem. The sunken greenbelt is set up in the community to accommodate the excess rainwater on the ground. When the surface runoff exceeds the capacity of the infiltration, the accumulated water in the community can be timely cleared, and the green area can be increased for the community. In the sunken green space, spring and summer blooming wet plants should be planted to achieve the effects of low conservation costs, high ornamental value, and long aging time, and to retain and purify rainwater during rainfall.

\subsection{Community road and parking lot design}

A cover plate type seepage ditch is provided in the middle of the parking lot to allow the infiltration of excess rainwater into the permeable pavement, increase the infiltration rate of rainwater, reduce water accumulation on the road surface, and provide convenience for people to travel. The sunken green space is convenient for rainwater runoff from the pavement, adds greenery to the community, and creates a good landscape effect, thereby reducing rainwater runoff from the pavement in the community and improving the landscape quality of the community.

\subsection{Design of Underground Garage Roof}

The rainwater on the roof of the building in the small area flows to the ground through the roof rain pipe, and is collected into the cover type seepage ditch, and some of it infiltrates, and the other is collected in the pump well for recycling. The design of the green roof of the underground garage can not only provide a place for people to entertain and entertain, but also play a role in absorbing rainwater, reducing rainwater runoff on the pavement, and reducing surface pollution from rainwater. The rainwater runoff in the green space will be collected into the cover plate infiltration ditch through the overflow port when the rainfall exceeds the standard, and the excess rainwater will eventually be merged into the pump well through the connecting pipe and temporarily stored in the pump well for the later greening. Watering with water.

\section{Conclusion}

Wuhan has unique natural water resources, numerous lakes, and a good skeleton that forms a natural "green sponge", providing ample space for rainwater flood storage. But with the intensification of Wuhan infrastructure construction, many lakes have been buried, and the city is evolving into a "hard-shell city" made of reinforced concrete. The content of artificial urban sponges is very extensive, mainly including a series of low-impact development facilities such as sunken green areas, rain gardens, artificial rain wetlands, permeable pavements, and green roofs. These artificial urban sponges are modeled on the working principle of natural sponges and use artificial means to regulate the storage of rainwater, which has achieved a considerable effect in cities with a high degree of natural sponges. Using the sponge city concept to guide the landscape reconstruction design and rainwater treatment of residential quarters can not only create a good landscape space for people, but also avoid floods caused by rainwater.

\section{References}

1. Liu H.M., Sun W.J., Shen S.L., et al. Flood risk assessment in metro systems of mega-cities using a GIS-based modeling approach. Science of The Total Environment, 626:1012-1025 (2018)

2. Zoppou C., Review of urban storm water models. Environmental Modelling \& Software, 16(3):195231(2001)

3. Li J., Deng C., Li Y., et al. Comprehensive Benefit Evaluation System for Low-Impact Development of Urban Stormwater Management Measure. Water Resources Management, 31(14):1-14(2017)

4. Liu B., Yi P., Water Saving Retrofitting and Its Comprehensive Evaluation of Existing Residential Buildings. Energy Procedia, 14:1785(2012)

5. Li J, Deng C., Li H.. Hydrological Environmental Responses of LID and Approach for Rainfall Pattern Selection in Precipitation Data-Lacked Region. Water Resources Management, 32:4(2018)

6. Wu Lianfeng, A case study of the sponge city construction plan in built-up areas, Water\& Wastewater engineering, Vol. 45 -11(2019)

7. Gong C. Changjuan H., The way of constructing green block's eco-grid by ecological infrastructure planning, Procedia engineering, 145,1580-1587 (2016) 